\title{
Research on the Application of Computer Network Technology in University Archives Management
}

\author{
Liying CUI ${ }^{1, a}$, Haiyan ZHOU ${ }^{2, b}$ Qun $\mathrm{LI}^{3, \mathrm{c}}$ \\ 1,2,3 Jilin Agriculture University, Changchun, 130118, China \\ aemail:cuiliying07@126.com, bemail:.99128742@qq.com, cemail: liqun1968126.com
}

Keywords: Computer, Network technology; Archives management

\begin{abstract}
Computer network technology has been popularized in social development, and it plays an important role in various fields. In order to adapt to and promote the development of colleges and universities, it is necessary to improve the efficiency of university archives management. It is necessary to adopt computer network technology in the archives management work. University archives management is an important part of the university management, which has important significance for promoting the smooth development of teaching, scientific research, infrastructure and so on. This paper analyzes the problems existing in the archives management in colleges and universities, and discusses the application of computer network technology in the archives management in colleges and universities.
\end{abstract}

\section{Introduction}

The current rapid development of higher education enterprise in our country, university departments work has also been gradually improve, with an increase in the number and variety of college archives, the difficulty of management also gradually increased. Traditional archive management mode has been far can not adapt to social development demand, thus improve the efficiency of archive management in colleges and universities, effective measures must be taken.

\section{Problems existing in the archives management of colleges and universities}

\section{Insufficient attention to file management}

Most of the college archives is given priority to with paper, large quantity and many kinds of, file management has the certain difficulty. Some universities did not attach enough importance to file management, manpower and financial investment is not enough, the departments file consciousness, file management personnel can only on a large number of files and collection of simple, no attention fully dig the use value of the archives information resources waste phenomenon to appear archives resources[1].

\section{Archives management is not adapt to the rapid development of modern society}

The rapid development of information technology, the rapid increasing of social information archives management work faces enormous challenges, the traditional management pattern has greatly hindered the development of archival undertaking, therefore, must change the traditional management ideas and methods, to adapt to the new requirements of information society. Though many colleges and universities archives management department has been equipped with the 
corresponding equipment, modern management gradually in the realization of the computer network management, in the actual file management, there is also a serious shortage, archives database construction existence insufficiency, mainly catalog database, the imperfection of the full text database and multimedia database construction, audio and video, such as physical carrier files exist are few in number. In the modern computer network environment, the traditional management mode can't meet a variety of needs of users, more conducive to the higher education each work smoothly.

\section{Expired files do not clean up in time}

Archives of the duration is divided into short-term, long-term, permanent three, under the traditional archive management mode, due to inventory have difficulty in archives work carefully, the staff have enough accurate information on file storage time, causing a large number of invalid file cannot be processed in time, sometimes because of the appraisal and review process cumbersome and not for processing, all these bring extra burden to management.

\section{File management personnel service ability and service quality improvement}

College archives management work is a professional strong work, need archives management personnel have certain professional knowledge and skills, also has the information development skills. File is not sealed in the information resources, comprehensive development and utilization of archives information resource is the fundamental aim of archives work. At present, the full development and utilization of file information resources is a very important work of archives. Archives management needs to efforts to create favorable conditions, full use of modern means of computer information management, timely, accurate, scientific and efficient development of archives information resources for the development of higher education services[2]. Due to the value of archives management of colleges and universities is not enough, the structure of the file management personnel is not reasonable, no some archives management system of professional training, professional qualities and skills is not high, familiar with modern computer network technology is not enough, cannot master the skilled operation skills, cannot make archives in colleges and universities give full play to the role, to promote the development of higher education cause waste within the archive information resources.

\section{Computer network technology in the application of the archives management of colleges and universities}

\section{Set by the user for the concept of modernization of file management}

The application of computer network information enable file service work faster and more convenient, the university archives should be with the purpose to "the use of user" for the service concept, establish the concept of archives management of computer network information, change the traditional management mode, fully aware of the archives management work for using the importance of computer network technology, the archive management gradually realize networking, information, digitalization. 


\section{Establish a perfect mechanism of archives management}

First of all, is the foundation of scientific archives management of colleges and universities archives management mechanism, need from the management of colleges and universities themselves, to realize scientific archives management of colleges and universities. College archives management, in the process of management work must strictly adhere to the principle of the modern management system, school should strengthen the supervision and control of college archives management work, play the role of education and motivation. Second, the scientific adjustment with good archivists in colleges and universities, to achieve scientific archives management of the foundation.

The cornerstone of the scientific management of archives in Colleges and universities is the archives management mechanism. University archives management personnel must adhere to the principle of management system, strengthen the supervision and control of school and play the role of education and motivation, scientific adjustment is equipped with the personnel of archives, to realize the scientific basis of archives management.

To establish a sound management mechanism of the university archives work, according to the relevant laws and regulations, improve the university archives management mechanism, and promote the development of archives. Scientific and reasonable system of the archives management, the establishment of ensure file collection, collation, filing, storage, use the various aspects coordinated development, the establishment of the corresponding file system, encourage managers to enhance their professional qualities. In order to realize the scientific development goal of the University Archives Management in our country, establish a scientific quality of the file management team, improve the university archives management level. The management level of ascension archives management and service ability

Improve the level of scientific archives management, the most important thing is to strengthen the "people" the quality of construction. File management directly depends on the quality and efficiency of archives management personnel's quality and ability, so colleges and universities must establish a strong team with high qualification and professional information technology file management team[3]. To promote the archives management of colleges and universities to realize network information, more standardized and scientific management, must give full play to the personnel file management capabilities. File management personnel in addition to the need to have the basic operation skills and the ability of archives management, also requires mastering modern archives management technology, such as a large number of archives in colleges and universities to make use of a computer program of scientific and accurate classification, archive, group, etc., also cultivate archives management personnel to use computer terminals, data type, database construction, encryption technology, network management and network security skills, etc., to adapt to the development of archives management technology[4]. High quality talent team will provide a strong intellectual support and talent guarantee for improving the scientific level of archives management.

The importance of archives information management in computer network technology training. Education training work, improve the file management of the business skills, be familiar with and proficient in the use of computer network technology, strengthen the responsibility consciousness, 
promote the improvement of professional ethics, can fully into the university archives management work, to better meet the needs of the archives management modernization, promote the development of archives in colleges and universities. The application of computer network technology can effectively improve the efficiency of the management of archives information, improve the management level. Improve the staff's work responsibility consciousness, by implementing the responsibility of archives information management, ensure the smooth operation of the work of archives information, most likely to reduce the loss of the archives information and the entity file damage phenomenon. As records management staffs also need to further improve their service consciousness, the staff should fully realize the importance of archives information, constantly improve their service consciousness, changing the concept of work, improve the level of file management.

\section{Archives information network with computer network technology in the application of university archives}

Computer network technology in the application of university archives information management, implementation file convenient, intelligent information retrieval way, promote the archives management information network, realize the resource sharing of archives information. As the computer network technology level unceasing enhancement, the demand of archives also gradually increased, archives resources to make use of computer network technology collection, processing, processing, utilization, improve the efficiency of resource utilization, archives also prompted the archives management work actively and orderly development. Application of computer network technology is inevitable trend in the development of the current university archives management work, make full use of the computer network technology, promote the university archives management work in the direction of the information, automation, scientific development, make full use of the archives resources, make the education teaching work orderly.

Computer network technology applied to archives management of colleges and universities, first of all, we will further improve the file information database, to ensure the effective management of archives information and full use. The carrier of information resource file database must improve, for different university archives information for a reasonable classification, ensure the effective information extraction. The construction of archives information without reasonable maintenance work, by the use of future often may make the information in the file information will appear some problems, archives information database maintenance work is necessary to strengthen. Records management department should regularly to update and check the file information, to ensure the integrity of the archives information. Effective service as the starting point of how to realize the file information, will be how to realize the maximum utilization of archives information included in the database construction of consideration, guarantee information database construction can give full play to its function, improve the utilization of archives information.

\section{Conclusion}

Along with the development of computer network technology, the development of the university archives information of a large number of increase, realize the university archives information of the computer network management mode is important. University archives management work is to 
further improve the construction of archives information database, improve the management of the archives management of the computer network management, the application of computer network technology in the actual file management[5]. The university archives management personnel need to change the work idea, improve the service consciousness of the archives management, make full use of the advantages of the computer network technology, ensure the effective utilization of the archives information, and promote the development of higher education.

\section{Acknowledgements}

In this paper, the research was sponsored by the

\section{References}

[1] Zhuang Qianqian. Information technology in archives management in the application of [J].. business office 2015,18:9

[2] Beilei Liu. The application of computer network technology in the archives management of colleges and universities [J]. new campus (early days) 2015, 02:136

[3] Zhang Jianxi. The application of computer network technology in the university personnel file management [J]. Technology innovation and application, 2013, 20: 71

[4] Yang Zhe. The application of computer network technology in college file management [J]. Journal of Changchun University of Science and Technology (SOCIAL SCIENCE EDITION), 2008,04:135-136

[5] Jing Wang. The application of computer network technology in the file management [J]. office business, 2015,18:89. 